\title{
Microbiological nitrogen transformation in carbonate sediments of a coral-reef lagoon and associated seagrass beds
}

\author{
Toshihiro Miyajima ${ }^{1, *}$, Masahiro Suzumura ${ }^{2}$, Yu Umezawa ${ }^{1}$, Isao Koike ${ }^{1}$ \\ ${ }^{1}$ Marine Biochemistry Laboratory, Ocean Research Institute, The University of Tokyo, Minamidai 1-15-1, Nakano, \\ Tokyo 164-8639, Japan \\ ${ }^{2}$ Environmental Assessment Department, National Institute for Resources and Environment, Onogawa 16-3, Tsukuba, \\ Ibaraki 305-8569, Japan
}

\begin{abstract}
Nitrogen fixation (NF), denitrification (DN), microalgal uptake (MU) of dissolved inorganic nitrogen (DIN) and the net diffusive DIN flux (FL) between the sediment and the overlying water were measured in bare carbonate (sand) sediment and seagrass-bed sediment of the shallow $(<3 \mathrm{~m})$ backreef lagoon of a fringing coral reef off Ishigaki Island in the western subtropical Pacific. Nitrogen metabolisms were generally more active in seagrass-bed sediment than in bare carbonate sediment, and in summer than in winter. Bottle-incubation experiments showed that the top $1 \mathrm{~cm}$ layer of sediments actively absorbed nitrate and ammonia through photosynthetic processes by benthic microalgae. Light dependence was observed for nitrate uptake, but not for ammonium uptake. MU had a much larger potential flux than NF, DN and FL, while the latter 3 fluxes displayed the same order of magnitude among sites and seasons. Dark incubation of intact cores for FL measurements resulted in nitrate uptake and ammonia release from the sediments, suggesting that the source of ammonia for the microalgae at the surface layer was the pore-water pool, while nitrate was mainly supplied from the overlying water. These results suggested that internal cycling between the surface MU and regeneration at deeper layers principally regulates nitrogen flux and distribution in these shallow carbonate sediments. The presence of microalgae effectively reduced the diffusive loss of nutrients from the sediments, enhancing accumulation of combined nitrogen in otherwise highly oligotrophic carbonate sediments. The sum of the external fluxes (NF, DN, FL) indicated net accumulation of combined nitrogen (i.e. inorganic nutrient and organic nitrogen) in the sediments. It is hypothesized that a significant amount of combined nitrogen is exported from the sediments by processes such as resuspension and grazing of organic detrital particles derived from microalgae and seagrasses in order to balance this accumulation.
\end{abstract}

KEY WORDS: Coral reef · Nitrogen fixation · Denitrification · Sediment-water flux · Microalgae · Seasonal change

Resale or republication not permitted without written consent of the publisher

\section{INTRODUCTION}

Transport and recycling of nitrogen are key factors supporting the high primary productivity of coral reefs and associated seagrass beds in oligotrophic tropical

*E-mail: miyajima@ori.u-tokyo.ac.jp marine environments. Coral reefs utilize dissolved and particulate nitrogen from advected oceanic water, wet and dry precipitation, river and ground waters, and combined nitrogen fixed within the reef as nitrogen sources. Coral reefs often export nitrogen to the open ocean (Webb et al. 1975); however, the exchange of dissolved inorganic nitrogen (DIN) with the open ocean by advection does not seem to limit their pro- 
ductivity (Wiebe 1985). It has been hypothesized that internal storage and recycling of nitrogen rather than exchange with the open ocean constitute the main pool and pathway on which the coral-reef biota depends (Lewis 1977, D'Elia \& Wiebe 1990), although direct evidence of this is scarce. Thus, it can be presumed that benthic processes (as opposed to water-column processes) are important in the regulation of the nitrogen budget in environments such as coral reefs and seagrass beds in which the residence time of seawater is relatively short (D'Elia \& Wiebe 1990, Hemminga et al. 1991). How the benthic subsystem of the coral reefs can acquire, accumulate and export nitrogen is therefore crucial to the understanding of what controls productivity and the nutrient status of coral-reef and seagrass-bed ecosystems.

The benthic system of coral reefs may acquire nitrogen through active biological uptake and passive diffusion of DIN from the overlying seawater, in situ nitrogen fixation, sedimentation of particulate organic nitrogen, and submarine groundwater discharge. Nitrogen may be exported from the benthic systems through diffusional efflux of dissolved nitrogen to the overlying seawater, resuspension and flushing-out of sedimentary organic nitrogen and dead biomass, and denitrification. Many studies have suggested the significant contribution of nitrogen fixation to the nitrogen budget in carbonate sediments (Wiebe et al. 1975, Larkum et al. 1988, O'Neil \& Capone 1989, Capone et al. 1992). Nevertheless, little is known about the fate of the fixed nitrogen. It has been shown that regenerated ammonium from reef sediments is a relatively unimportant nitrogen source for reef primary production (Williams et al. 1985, Hopkinson et al. 1987, CharpyRoubaud et al. 1996). There is little consensus about the relative importance of denitrification, diffusional influx, in situ microalgal uptake, and sedimentation and resuspension of particulate organic matter in the nitrogen budget of the benthic system. A few studies have illustrated the potential importance of these processes (Corredor \& Capone 1985, Capone et al. 1992, Boucher et al. 1994, Miyajima et al. 1998). To estimate the magnitude and identify the mechanisms of accumulation and export of total nitrogen by the benthos, the representative components of the benthic fluxes must be accurately and simultaneously quantified.

In this study, we estimated the nitrogen flux in carbonate sediment off Ishigaki Island in the western subtropical Pacific. A comparison was made between rates of nitrogen fixation, denitrification, sediment-water fluxes and nutrient uptake by benthic microalgae in a typical coral-reef sediment without any macrophyte vegetation and in sediment of associated seagrass beds. Using these data, we examined the following hypotheses: (1) the soft-bottom lagoon sediment, which usually occupies the major part of the reef bottom, is a net source of combined nitrogen; (2) internal nitrogen recycling in this sediment is more important than external nitrogen supply.

\section{MATERIALS AND METHODS}

Study site and sampling. This study was carried out at Shiraho Reef, to the east of Ishigaki Island in the western subtropical Pacific $\left(24^{\circ} 25^{\prime} \mathrm{N}, 124^{\circ} 20^{\prime} \mathrm{E}\right.$ : Nakamori et al. 1992). Shiraho Reef is a fringing coral reef with a reef crest ca $800 \mathrm{~m}$ off the shoreline and a shallow lagoon (up to $3 \mathrm{~m}$ below mean sea level) inside. Typical belt-like zones of vegetation are present in the lagoon: seagrass beds occur up to ca $300 \mathrm{~m}$ offshore (Tanaka 1999); large patches of live corals are abundant at 500 to $700 \mathrm{~m}$ offshore; the seaward area of the reef crest ( 700 to $800 \mathrm{~m}$ offshore) is covered with dense brown algae from spring to autumn (mainly Sargassum spp. and Padina spp.). Most of the remaining area of the lagoon is devoid of macrophytes or corals, being composed of typical carbonate sand, although the sand coverage on the bedrock is thin (typically $<50 \mathrm{~cm}$ deep). Sheet-like green algae such as Ulva spp. proliferate during winter on the intertidal reef rocks near the shoreline. Groundwater seeps from several points along the shoreline during low tide period (Umezawa 2000). Groundwater-loaded seawater flows along the shoreline, and it is eventually flushed out from the channels of the reef crest to the north or south of the study area, depending on the wind direction.

Sediment samples were collected on 5 to 14 March 1998 (late winter, water temperature $=17$ to $25^{\circ} \mathrm{C}$ ) and 1 to 4 September 1997 and 12 to 20 September 1998 (late summer, 27 to $33^{\circ} \mathrm{C}$ ), at 2 sites. One site was ca $500 \mathrm{~m}$ offshore, where bare carbonate sand is exposed without visible vegetation and the sediment consists of relatively coarse, pure carbonate grains typical for pristine coral reef lagoon. The other site was ca 150 m offshore in a patch of the seagrass Thalassia hemprichii. The sediment underlying this seagrass meadow is fine carbonate sediment containing a small fraction of siliceous mud derived from the land. Judging from the water-flow regime, groundwater does not penetrate farther than $300 \mathrm{~m}$ from the shoreline, but often flows over the seagrass meadow site. The concentration of $\mathrm{NO}_{3}{ }^{-}$in the seagrass-beds increases at ebb tide due to groundwater contamination; the maximum value observed was ca $50 \mu \mathrm{M}$. The concentrations of $\mathrm{NO}_{2}{ }^{-}$and $\mathrm{NH}_{4}{ }^{+}$in the groundwater were not significantly different from those in the seawater of the lagoon.

Samples for the determination of nitrogen fixation and denitrification activities, sediment-water flux measurements, and pore-water nutrient profiles were obtained 
at both sites. In addition, samples were collected near an intertidal groundwater-seepage zone for denitrification measurement and pore-water analysis, and at several places in the bare sand area for measurements of nutrient uptake by benthic microalgae. Macrophytes were collected from both sites to quantify nitrogen fixation by attached bacteria and cyanobacteria. Seawater was collected near the sampling sites and filtered through a Whatman GF/F filter before use in the incubation experiments or for pore-water extraction.

Sediments for flux measurements and pore-water analyses were sampled with acrylic cores (i.d. = $50 \mathrm{~mm}$; length $=300 \mathrm{~mm}$ ) with silicone rubber plugs and transferred to the laboratory together with the overlying seawater. For nitrogen fixation and denitrification measurements, the top $5 \mathrm{~cm}$ sediment layer was collected with a spatula and transferred to a polyethylene container together with the overlying seawater. For microalgal uptake measurements, the top $1 \mathrm{~cm}$ layer of sediment was collected. Samples were transferred to the laboratory, and incubation experiments were started within $5 \mathrm{~h}$ of collection. Cores for porewater extraction were temporarily stored in an ice bath, and the pore water was extracted on the same day as sampling.

Pore-water extraction. Sediment cores were cut into 2 to $3 \mathrm{~cm}$ sections with a spatula, and each section was transferred to a polyethylene bag. After the wet weight had been determined, $10 \mathrm{ml}$ of nutrient-free filtered seawater was added to the bag and mixed thoroughly with the sediment. The supernatant was then filtered through a Whatman GF/F into a $10 \mathrm{ml}$ acrylic tube and stored frozen for later analysis. The solid fraction was dried at $60^{\circ} \mathrm{C}$ and measured for dry weight to estimate water content. Nutrient concentrations in the original pore water were calculated from the concentrations in the extract and the water content of the sediment. The dried sediments were analyzed for organic carbon and total nitrogen contents (see below).

Nitrogen fixation. The nitrogen fixation activity of sediment microorganisms and attached algae was measured by a ${ }^{15} \mathrm{~N}_{2}$ tracer method (Seitzinger \& Garber 1987). Approximately $10 \mathrm{~g}$ (wet weight) of sediment, or a small fragment of macrophytes (1 to $5 \mathrm{~g}$ wet weight), was added to a glass tube (i.d. $=20 \mathrm{~mm}$, length = $100 \mathrm{~mm}$ ), which was then filled with filtered seawater and plugged at both sides with butyl-rubber double caps. Care was taken to avoid occurrence of air bubbles in the tubes. Five $\mathrm{cm}^{3}$ of ${ }^{15} \mathrm{~N}_{2}$ gas $\left(99 \%{ }^{15} \mathrm{~N}\right.$, Isotec Inc., Miamisburg, USA) was injected into the tubes through the rubber caps using a gas-tight syringe (10 ml, Dynatech Inc., USA). The seawater inside the tubes was allowed to overflow through a second syringe needle. For dark incubation, tubes were wrapped with aluminum foil. The tubes were placed in a shallow, dark-blue con- tainer filled with running tap water to stabilize temperature and incubated for 1 to $3 \mathrm{~d}$ under natural light regimes. Replicate experiments were performed for each sample and setting $(n=6$ for light-incubated sediments, $\mathrm{n}=3$ for dark controls and plant and rhizosphere samples). Water temperature and underwater light intensity were monitored during incubation. After incubation, the seawater in the incubation tubes was decanted, and sediments and plant materials were recovered in small polyethylene bags. The bags were then frozen temporarily for transportation. The measured incubation temperature $\left(21\right.$ to $24^{\circ} \mathrm{C}$ in March, 28 to $31^{\circ} \mathrm{C}$ in September) was similar to, but less variable than, the in situ water temperature (see above).

Rhizosphere sediments of Thalassia hemprichii and Halimeda sp. (i.e. sediments loosely associated with fine roots of $T$. hemprichii or holdfast of Halimeda sp.) were similarly incubated with the above-ground portions of the plants. After incubation, above-ground portions and large rhizome fragments were removed and the remaining sediment fraction retained for later analysis.

Sediments and plants were dried in a vacuum oven $\left(60^{\circ} \mathrm{C}\right)$; their dry weight was determined, and they were powdered using a blender. Small fractions of substrate sediments (50 to $80 \mathrm{mg}$ ), rhizosphere sediment (20 to $50 \mathrm{mg}$ ) and plant materials (5 to $10 \mathrm{mg}$ ) were placed separately into tin containers and subjected to isotope-ratio analysis using a mass spectrometer (ANCA-MS interfaced with a combustion furnace ROBOPREP, Europa Scientific Co., Crewe, UK), for determination of nitrogen content and ${ }^{15} \mathrm{~N}$ concentration. Duplicate samples were analyzed.

The amount of nitrogen fixed during incubation was calculated from the measured ${ }^{15} \mathrm{~N}$ concentration, with a correction for carry-over of ${ }^{14} \mathrm{~N}_{2}$ from the filtered seawater used as incubation medium, assuming diffusion equilibrium (Kester 1975). It was assumed that the seawater was saturated with atmospheric $\mathrm{N}_{2}$.

Denitrification. The denitrification activities of sediments amended with various amounts of $\mathrm{NO}_{3}^{-}$were determined. In situ activity was estimated from a plot of denitrification activity versus $\mathrm{NO}_{3}{ }^{-}$concentration by substituting the pore-water $\mathrm{NO}_{3}{ }^{-}$concentrations (Joye et al. 1996).

Denitrification activities in $\mathrm{NO}_{3}{ }^{-}$-amended sediments were detected by acetylene $\left(\mathrm{C}_{2} \mathrm{H}_{2}\right)$ inhibition as follows: From the sediment sample stored in a plastic container (a mixture of the top $5 \mathrm{~cm}$ layer), subcores (ca $30 \mathrm{~g}$ wet weight) were withdrawn using glass tubes (i.d. $=20 \mathrm{~mm}$, length $=200 \mathrm{~mm}$ ), and the bottom of the tubes were plugged with butyl-rubber double caps. The wet weight of the sediment was measured. Two ml of filtered seawater containing various concentrations of $\mathrm{NaNO}_{3}$ (0 to $5 \mathrm{mM}$ ) and $1 \mathrm{ml}$ of $\mathrm{C}_{2} \mathrm{H}_{2}$-saturated fil- 
tered seawater were added to the tubes. The tubes were immediately closed at the top with a butyl-rubber double cap and shaken several times manually to enhance diffusion of $\mathrm{NO}_{3}{ }^{-}$and $\mathrm{C}_{2} \mathrm{H}_{2}$. Incubation was performed in the dark and at room temperature. Five $\mathrm{ml}$ of head-space gas of each tube was sampled at $t=0,4,8$, and $12 \mathrm{~h}$ through a double needle into a vacuum blood tube $(5 \mathrm{ml})$. Prior to sampling, the tubes were shaken several times to equilibrate produced $\mathrm{N}_{2} \mathrm{O}$ with the head space. After incubation, the content of the tubes were transferred to polyethylene bags. The sediment was dried at $60^{\circ} \mathrm{C}$ and the dry weight and the water content were recorded. The $\mathrm{N}_{2} \mathrm{O}$ in the head-space gas was determined on a gas chromatograph (GC-14B, Shimadzu, Japan) equipped with an electron-capture detector. A portion of original sediment samples was used for pore-water extraction, and the extracts were determined for $\mathrm{NO}_{3}{ }^{-}$concentration.

The concentration of $\mathrm{NO}_{3}{ }^{-}$in the incubation medium was calculated for each tube from the $\mathrm{NO}_{3}{ }^{-}$concentration in the pore water of original sediment, the water content, and the amount of amended $\mathrm{NO}_{3}{ }^{-}$. The $\mathrm{N}_{2} \mathrm{O}$ production decreased during incubation, presumably due to exhaustion of the added $\mathrm{NO}_{3}{ }^{-}$. The $\mathrm{N}_{2} \mathrm{O}$ production rate at the initial $\mathrm{NO}_{3}{ }^{-}$concentration in each tube was estimated by fitting a hyperbolic curve to the plot of $\mathrm{N}_{2} \mathrm{O}$ production versus time by the least-squares method and calculating the slope of the curve at $t=0$. The estimated $\mathrm{N}_{2} \mathrm{O}$ production rates were plotted against the initial concentration of $\mathrm{NO}_{3}{ }^{-}$in the medium. When these plots were similar to a saturation curve, the Michaelis-Menten rate constants $K_{\mathrm{m}}$ and $V_{\text {max }}$ were calculated by the least-square method. When the $\mathrm{N}_{2} \mathrm{O}$ production rates did not saturate over the range of $\mathrm{NO}_{3}{ }^{-}$concentrations tested, the rate was linearly regressed against the $\mathrm{NO}_{3}{ }^{-}$concentration and the slope of the regression was determined.

Microalgal uptake. Nutrient uptake rates by the microorganisms in the top $1 \mathrm{~cm}$ of the sediments were measured by light-and-dark bottle incubations. We refer to this measured uptake rate as the uptake by epibenthic microalgae, although it may be partially ascribable to assimilative uptake by heterotrophic bacteria. As shown in the 'Results' section, $\mathrm{NO}_{3}{ }^{-}$ uptake by denitrifying bacteria could be assumed to be negligible. The epibenthic microflora at the study site consisted mainly of diatoms, flagellated algae and cyanobacteria (M.S. unpubl. data).

In order to remove nutrients contained in the pore water, the collected sand samples were washed gently by soaking in ca 41 nutrient-depleted seawater and retrieved on a stainless steel sieve (200 $\mu \mathrm{m}$ mesh). Large gravel, if any occurred, was removed. The washed sediment ( 10 g wet weight) was transferred to glass bottles (Duran ${ }^{\circledR}$, ca $300 \mathrm{ml}$ ), and the bottles were filled with lagoon seawater. Bottles containing only seawater were used as blanks. In some cases, extra $\mathrm{NO}_{3}{ }^{-}$was spiked before incubation to examine the dependence of $\mathrm{NO}_{3}{ }^{-}$uptake on the concentration of $\mathrm{NO}_{3}{ }^{-}$. A portion $(10 \mathrm{ml})$ of the added seawater was stored frozen and used as the $t=0$ sample. Bottles were incubated for $24 \mathrm{~h}$ (September 1997) or 4 to $6 \mathrm{~h}$ in the daytime (March 1998) either at the bottom of the sampling sites (7 March 1998) or in a manner similar to the nitrogen fixation measurements (September 1997 and 11 March 1998). The ambient water temperature and light intensity were monitored with a quantum monitor (Biospheric Instrument Inc., San Diego, USA, IMF300). Dark-control bottles were prepared by wrapping the bottles with aluminum foil. After incubation, a portion of the bottle water was immediately filtered $(\mathrm{GF} / \mathrm{F})$, transferred to acrylic tubes $(10 \mathrm{ml})$ and frozen for transportation and storage. The uptake rates of DIN by the microalgae were determined from the difference in the DIN concentrations at the beginning and at the end of incubation.

Sediment-water exchange. The exchange of nutrients between the sediment and the overlying water in the dark was estimated by incubating intact sediment cores (i.d. $=50 \mathrm{~mm}$, length $=300 \mathrm{~mm}$, sediment filled to about half the height of the core) and monitoring temporal changes in nutrient concentrations in the overlying water. The original overlying water of the sediment cores had been carefully removed by siphoning to exclude disturbance effects during sample collection and transportation. The sediment surface was gently overlaid by filtered seawater collected near the sampling site to a depth of ca $10 \mathrm{~cm}\left(200 \mathrm{~cm}^{3}\right.$ vol.) by a peristaltic pump. The cores were incubated at room temperature under a black sheet. The overlying water was gently aerated with acid-washed $\left(2 \mathrm{M} \mathrm{H}_{2} \mathrm{SO}_{4}\right)$ air using a peristaltic pump throughout the incubation. The overlying water was subsampled at 6 to $12 \mathrm{~h}$ intervals into acrylic test tubes $(10 \mathrm{ml})$ and immediately frozen. To correct for water-column processes, the filtered seawater was incubated separately without sediments, and changes in its nutrient concentrations were checked. To assess the effect of biological nutrient uptake and release as opposed to abiotic diffusion from the pore-water pool, some cores were incubated with a metabolic inhibitor, sodium azide $\left(\mathrm{NaN}_{3}\right.$, final conc. of $2 \mathrm{mM}$ in the overlying water).

The amount of nutrients released or taken up by the sediment was calculated from the concentration in the overlying water and plotted against time; linear regression lines or hyperbolic curves were fitted, depending on the nature of the plots. Data from the first $48 \mathrm{~h}$ of incubation were usually used for curvefitting, although some data plots that had clearly been affected by contamination were omitted. When a plot 
fitted a hyperbolic curve, the slope at $t=0$ was regarded as reflecting the in situ sediment-water flux. Analytical methods. Nutrient $\left(\mathrm{NO}_{3}{ }^{-}, \mathrm{NO}_{2}{ }^{-}, \mathrm{NH}_{4}{ }^{+}\right.$, $\mathrm{PO}_{4}{ }^{3-}$ ) concentrations in the filtered seawater used for the incubation media, seawater samples from flux measurements, and pore-water extracts were determined using AutoAnalyzers II and AACS-II (Bran+ Luebbe, Hamburg, Germany). The $\mathrm{NO}_{2}^{-}$data with added $\mathrm{NaN}_{3}$ were not used, as the added $\mathrm{NaN}_{3}$ contained significant amounts of $\mathrm{NO}_{2}^{-}$.

Organic carbon and total nitrogen contents of carbonate sediments were determined according to the method of Miyajima et al. (1998) using an elemental analyzer (NA-1500, Fisons Instruments Inc., Beverly, USA). Chlorophyll $a_{\text {, }}(\mathrm{chl} a)$ in the sediment samples was extracted by $N, N^{\prime}$-dimethylfolmamide and quantified by spectrophotometry (Strickland \& Parsons 1968, Porra et al. 1989).

\section{RESULTS}

\section{Sediment chemistry}

Nutrient concentrations in the sediment pore water differed between the bare-sand area and seagrass beds, and between March and September (Fig. 1). Subsurface maxima in the profiles of $\mathrm{NO}_{3}{ }^{-}$and $\mathrm{NO}_{2}{ }^{-}$ were sometimes observed in summer (September 1998) profiles, presumably reflecting enhanced activity of nitrification. Such maxima were not evident in winter (March 1998). In the seagrass-bed sediment, $\mathrm{NO}_{3}{ }^{-}$was depleted below a depth of $10 \mathrm{~cm}$, presumably due to anoxic conditions. Ammonium concentration was much higher in seagrass-bed sediments than in bare-sand sediments, especially in summer. This may be ascribable to heterotrophic bacterial activity enhanced by the higher concentration of organic matter in the seagrass beds (see below).

Organic carbon contents were higher in the seagrassbed sediments than in the bare-sand sediments (data not shown). The acid (1.0 N HCl)-soluble fraction of organic carbon, which consisted mainly of small organic molecules in the carbonate minerals, was about twice as abundant in the seagrass-bed sediments (100 to $180 \mu \mathrm{mol} \mathrm{C} \mathrm{g}^{-1}$ ) than in the bare-sand sediments ( 66 to $80 \mu \mathrm{mol} \mathrm{C} \mathrm{g}^{-1}$ ). Concentration of acidinsoluble organic carbon (mainly detrital materials derived from algae and seagrasses) was about 5 times as high in the seagrass-bed sediments (190 to $380 \mu \mathrm{mol}$ $\mathrm{C}^{-1}$ ) than in the bare-sand sediments (45 to $57 \mu \mathrm{mol}$ $\mathrm{C}^{-1}$ ). Total nitrogen content followed a pattern similar to that of total organic carbon content ranging from 18 to 25 and 31 to $55 \mu \mathrm{mol} \mathrm{N} \mathrm{g}^{-1}$ for bare-sand and seagrass-bed sediments, respectively.
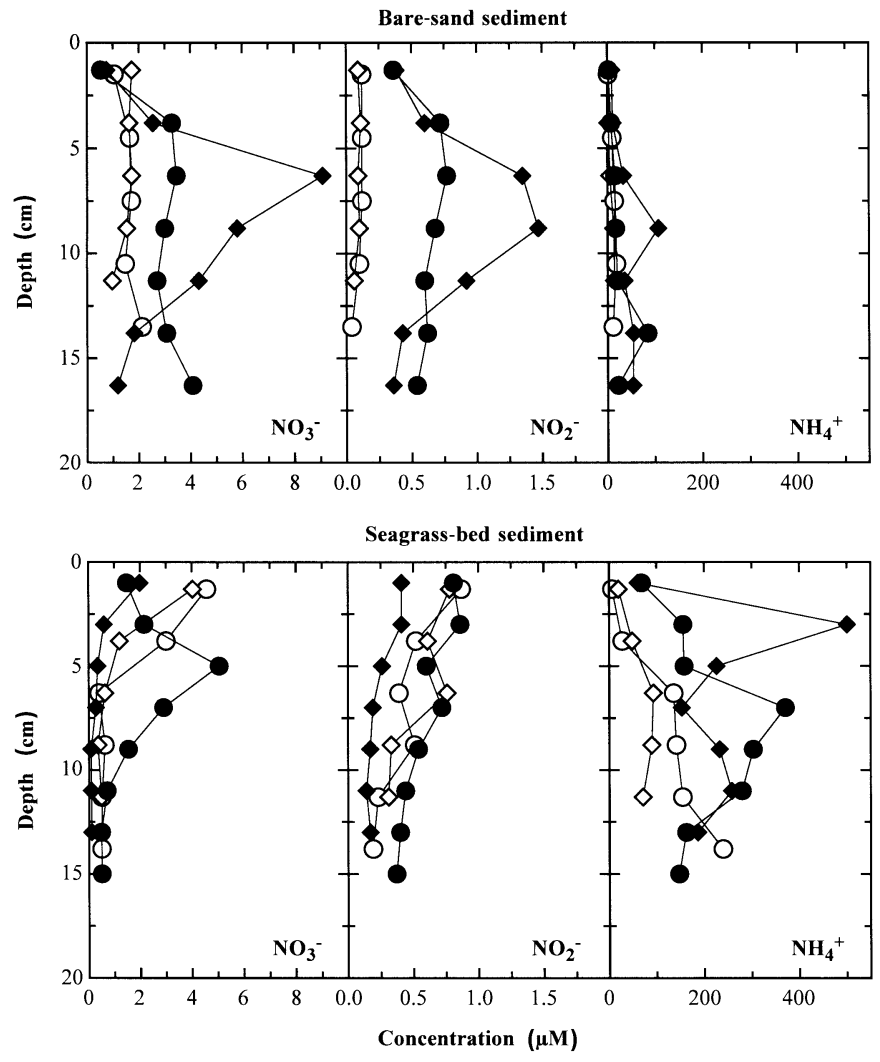

Fig. 1. Vertical profiles of DIN in pore waters extracted from bare-sand sediment and seagrass-bed sediment. $(0, \diamond)$ March 1998, $(\bullet)$ September 1998 (duplicate cores for each month)

\section{Nitrogen fixation}

Nitrogen-fixation activity was detected at significant levels in both the sediment and plant materials tested and was strongly dependent on light (Fig. 2, Table 1). Light dependence was more marked in sediment than in plant material. This may be ascribable to a larger organic carbon reserves in plant samples than in carbonate sand that would provide the energy and reducing power necessary for nitrogen fixation by heterotrophic bacteria in the dark. The time course of sediment incubations (Fig. 2) revealed a time lag prior to establishment of active nitrogen fixation in the light. Although we did not execute time-course experiments for plant samples, other researchers reported no, or much shorter $(<1 \mathrm{~h})$, time lags in nitrogen-fixation measurements of epiphytic cyanobacteria using the acetylene reduction method (e.g. Capone et al. 1977). However, Capone \& Taylor (1980) reported a time lag of 1 to $2 \mathrm{~h}$ during incubation of seagrass rhizosphere. Possible explanations for the relatively long lag time (ca 20 h) observed in our sediment incubation include: (1) tortuosity of sediment which would slow down diffusion rate of ${ }^{15} \mathrm{~N}_{2}$ compared to that in homogeneous 
Table 1. Rates of nitrogen fixation ( $\mathrm{nmol} \mathrm{N} \mathrm{g}^{-1} \mathrm{dry}_{\mathrm{wt} \mathrm{h}} \mathrm{h}^{-1}$ ) in the sediments and representative primary producers. Data are averages (SD); for sediments, average rates between 24 and $48 \mathrm{~h}$ of incubation are listed, for primary producers,

\begin{tabular}{|c|c|c|c|c|}
\hline Season, & \multicolumn{2}{|c|}{ Natural light } & \multicolumn{2}{|c|}{ Continuous dark } \\
\hline \multicolumn{5}{|l|}{ March 1998} \\
\hline Bare-sand sediment & 0.16 & $(0.03)$ & 0.02 & $(0.01$ \\
\hline Seagrass-bed sediment & 0.61 & $(0.21)$ & 0.02 & $(0.03$ \\
\hline \multicolumn{5}{|l|}{ September 1998} \\
\hline Bare-sand sediment & 0.89 & $(0.49)$ & 0.01 & $(0.06$ \\
\hline Seagrass-bed sediment & 1.23 & $(0.05)$ & 0.04 & $(0.04$ \\
\hline \multicolumn{5}{|l|}{ March 1998} \\
\hline Thalassia hemprichii, leaf & 1.65 & $(1.39)$ & nd & \\
\hline T. hemprichii, rhizosphere ${ }^{a}$ & 0.50 & $(0.07)$ & 0.13 & $(0.01)$ \\
\hline Halimeda sp., thallus ${ }^{\mathrm{c}}$ & 5.81 & $(0.25)$ & nd & \\
\hline Halimeda sp., rhizosphere ${ }^{b_{r} c}$ & 0.40 & $(0.15)$ & 0.05 & $(0.03$ \\
\hline Cyanobacterial mat ${ }^{\mathrm{d}}$ & 1.23 & $(1.22)$ & 0.65 & $(0.72$ \\
\hline \multicolumn{5}{|l|}{ September 1998} \\
\hline T. hemprichii, young leaf & 6.38 & $(5.08)$ & nd & \\
\hline T. hemprichii, old leaf & 39.02 & $(1.41)$ & nd & \\
\hline T. hemprichii, rhizosphere ${ }^{a}$ & 2.53 & $(2.16)$ & nd & \\
\hline Halophila sp., leaf & 9.14 & $(4.39)$ & nd & \\
\hline Halimeda sp., thallus ${ }^{\mathrm{c}}$ & 35.35 & $(6.64)$ & nd & \\
\hline Halimeda sp., rhizosphere ${ }^{\mathrm{b}, \mathrm{c}}$ & 9.55 & $(7.25)$ & nd & \\
\hline Cyanobacterial mat ${ }^{\mathrm{d}^{\mathrm{d}}}$ & 55.15 & $(27.46)$ & nd & \\
\hline \multicolumn{5}{|c|}{$\begin{array}{l}\text { a,b Incubated together with above-ground (green) parts of } T \text {. hemprichii and } \\
\text { Halimeda sp. } \\
{ }^{\mathrm{c} H} \text { Halimeda sp. collected near patches of seagrasses } \\
{ }^{\mathrm{d} C y a n o b a c t e r i a l ~ m a t s ~ c o l l e c t e d ~ f r o m ~ i n t e r t i d a l ~ r e e f r o c k s ~}\end{array}$} \\
\hline
\end{tabular}
the average rate of first $48 \mathrm{~h}$ of incubation

beds in winter, increased to 2 to 8 times the rate of the non-rhizosphere sediments in summer. This suggests that rhizomes of T. hemprichii and holdfasts of Halimeda sp. excrete larger amount of organic carbon available for nitrogen-fixing bacteria in summer than in winter, presumably as a result of the higher photosynthetic activity of these macrophytes in summer.

\section{Denitrification}

Denitrification $\quad\left(\mathrm{C}_{2} \mathrm{H}_{2}\right.$-induced $\quad \mathrm{N}_{2} \mathrm{O}$ production) rates in pristine carbonate sediments were very low under natural conditions. However, when the sediments were supplied with additional $\mathrm{NO}_{3}{ }^{-}$, measurable denitrification ensued (Fig. 3). In all 6 cases, significant positive correlation was observed between $\mathrm{NO}_{3}^{-}$concentration in pore water and denitrification rates ( $\mathrm{p}<$ 0.001). In summer (September 1998), the plots fitted Michaelis-Menten hyperbolic curves in seagrass-bed and groundwater-affected sediments. The slope of the fitted curves (at $\left[\mathrm{NO}_{3}{ }^{-}\right]=0$ for hyperbolic curves) was consistently aqueous solution, and (2) disturbance of the sediments during sample preparation, which should have caused shading of the $\mathrm{N}_{2}$-fixing epipsalmic cyanobacteria and the disappearance of anaerobic microhabitats necessary for heterotrophic $\mathrm{N}_{2}$ fixation.

To eliminate the effect of this lag, nitrogen-fixation rates in the sediments were determined from the difference in fixed nitrogen between 24 and $48 \mathrm{~h}$ of incubation (Table 1). For plant and rhizosphere samples, average fixation rates during the first $48 \mathrm{~h}$ of incubation were adopted, e.g. a time lag of 1 to $2 \mathrm{~h}$ for measurements of rhizosphere samples would mean a 2 to $4 \%$ underestimate of the actual rates.

In the sediments, the fixation rate was significantly higher in summer (September) than in winter (March) $(\mathrm{p}<0.0001$ for bare-sand area, $\mathrm{p}=0.0066$ for seagrass beds; 2 -tailed Student's $t$-test). The rate was also higher in the seagrass beds than in the bare-sand area ( $p=0.0015$ in March, but not significant in September). A similar seasonal pattern was observed in the fixation rates of plant samples. Remarkably, $\mathrm{N}_{2}$-fixation rates in the rhizospheres of Thalassia hemprichii and Halimeda sp. (i.e. sediments loosely associated with fine roots), which were not significantly different from those in non-rhizosphere sediment of the seagrass higher in summer than in winter (March 1998, Table 2). In each season, the slope was highest in the

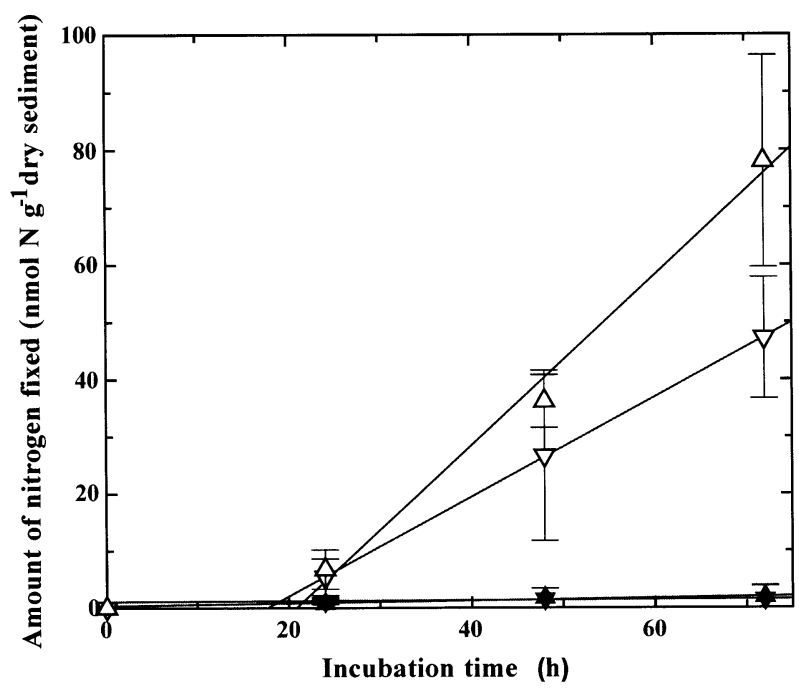

Fig. 2. Accumulation of nitrogen fixed from $\mathrm{N}_{2}$ in the sediments during incubation experiments in the light $(\Delta, \nabla)$ and dark $(\boldsymbol{\Lambda}, \boldsymbol{\nabla})$ (September 1998). $\left(\Delta_{,} \mathbf{\Lambda}\right)$ seagrass-bed sediment; $(\nabla, \boldsymbol{\nabla})$ bare-sand sediment. Error bars $=\mathrm{SD}$ of replicate incubations ( $\mathrm{n}=3$ to 6 ) 

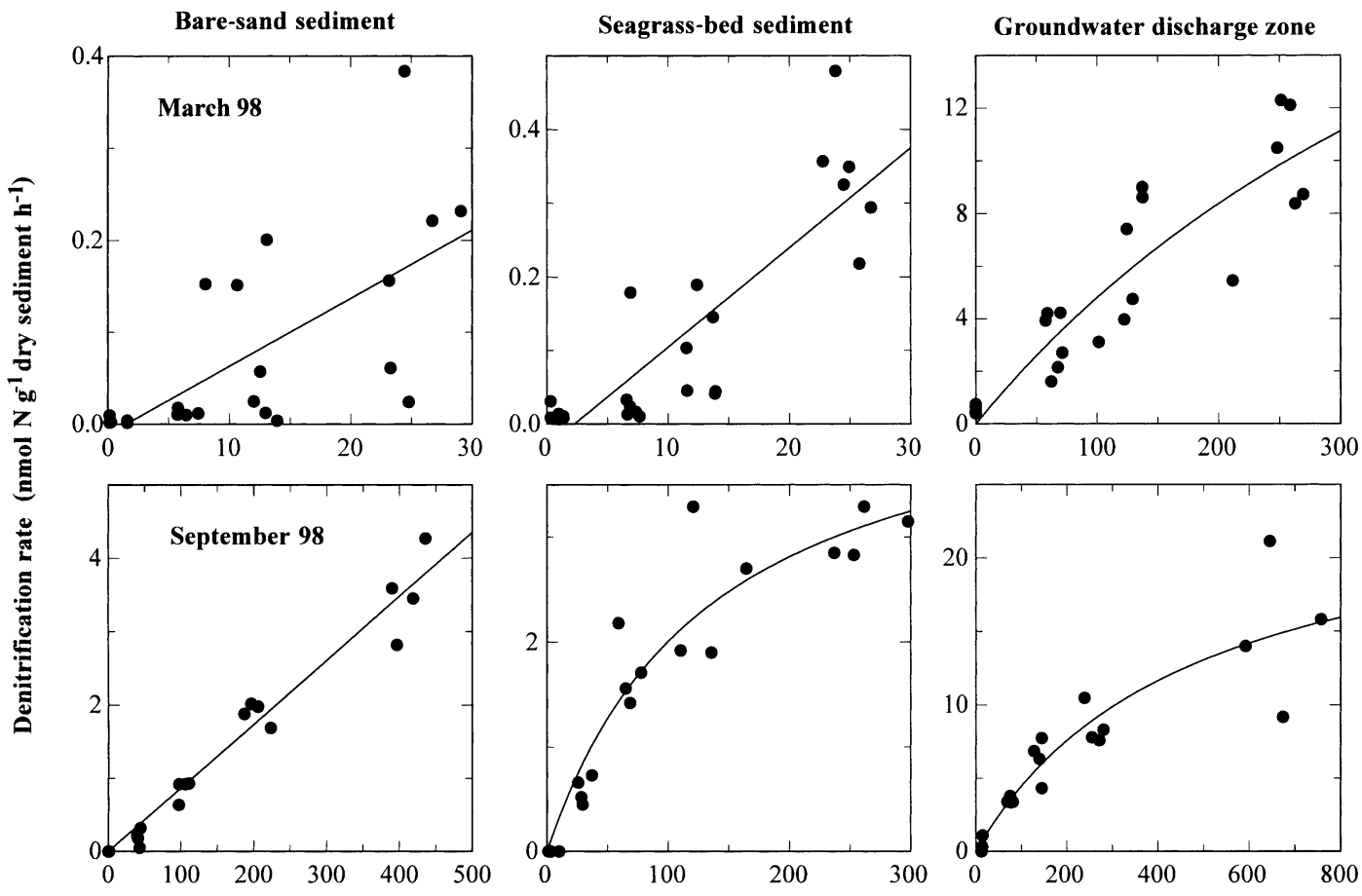

Concentration of $\mathrm{NO}_{3}^{-}$in pore waters $(\mu \mathrm{M})$

Fig. 3. Relationships between denitrification rate determined by acetylene inhibition method and concentration of $\mathrm{NO}_{3}{ }^{-}$in pore water in 3 different sediments in March 1998 and September 1998. Note different scales

sediment affected by groundwater and lowest in baresand sediment. In principle, the initial slope depends on the population density of active denitrifying bacteria, ambient temperature, oxygen tension, and the availability of organic carbon. The large slope in the groundwater-affected sediment is thought to result from high enzymatic activities of denitrifiers at the exceptionally high $\mathrm{NO}_{3}{ }^{-}$concentration (up to $300 \mu \mathrm{M}$ ) in this sediment.
By using measured pore-water $\mathrm{NO}_{3}{ }^{-}$concentrations (Fig. 1) and the fitted curves of corresponding sites and seasons, we calculated in situ denitrification rates and integrated them for the 0 to $15 \mathrm{~cm}$ depth interval of sediments (Table 2). The areal denitrification rate (integrated over 0 to $15 \mathrm{~cm}$ ) was generally higher in summer than in winter. No significant difference was found between the seagrass beds and the bare-sand area, while the rate at the groundwater-seeping area

Table 2. Denitrification rates in the sediments calculated from rate-concentration curves in Fig. 3 and pore-water nutrient profiles in Fig. 1 (integrated for the 0 to $15 \mathrm{~cm}$ depth interval). nd: no data

\begin{tabular}{|c|c|c|c|c|c|}
\hline \multirow[t]{2}{*}{$\begin{array}{l}\text { Season, } \\
\text { Sample }\end{array}$} & \multicolumn{2}{|c|}{$\begin{array}{l}\text { Denitrification rate } \\
\left(\mathrm{nmol} \mathrm{N} \mathrm{cm}^{-2} \mathrm{~h}^{-1}\right)\end{array}$} & \multicolumn{2}{|c|}{$\mathrm{NO}_{3}^{-}$turnover time } & \multirow[t]{2}{*}{$\begin{array}{l}\text { Initial slope of rate-concentration curve } \\
\qquad\left(10^{-6} \mathrm{l} \mathrm{g}^{-1} \mathrm{~h}^{-1}\right)_{i} \text { mean } \pm \mathrm{SD}\end{array}$} \\
\hline & Core-1 & Core-2 & Core-1 & Core-2 & \\
\hline \multicolumn{6}{|l|}{ March 1998} \\
\hline Bare-sand sediment & 0.20 & 0.17 & 61 & 68 & $6.8 \pm 1.1$ \\
\hline Seagrass bed sediment & 0.35 & 0.27 & 35 & 33 & $11.8 \pm 1.1$ \\
\hline Groundwater-seepage zone & nd & nd & nd & nd & $56.5 \pm 12.2$ \\
\hline \multicolumn{6}{|l|}{ September 1998} \\
\hline Bare-sand sediment & 0.44 & 0.65 & 46 & 48 & $8.7 \pm 2.6$ \\
\hline Seagrass-bed sediment & 1.18 & 0.28 & 13 & 14 & $35.0 \pm 6.2$ \\
\hline Groundwater-seepage zone & 96 & 130 & 8.1 & 9.8 & $54.2 \pm 11.4$ \\
\hline${ }^{\mathrm{a}}$ Calculated from data in Fig. 3 & & & & & \\
\hline
\end{tabular}


was more than 2 orders of magnitude higher than the rates in the former 2 sediments. In the bare-sand area, denitrification may also have occurred in sediments deeper than $15 \mathrm{~cm}$, since $\mathrm{NO}_{3}{ }^{-}$in pore water was not depleted at this depth (Fig. 1).

This method of estimating in situ denitrification rate is valid only if the rate is not as high as the diffusional mixing rate of the pore-water $\mathrm{NO}_{3}{ }^{-}$pool. In contrast, if nitrification and denitrification were sufficiently tightly coupled for $\mathrm{NO}_{3}{ }^{-}$produced by nitrifiers to be consumed rapidly by proximal denitrifiers before diffusing through the pore-water pool, then the average $\mathrm{NO}_{3}{ }^{-}$ concentration in the pore water would not reflect the actual $\mathrm{NO}_{3}{ }^{-}$concentration in the vicinity of active denitrifiers, and therefore the denitrification rate calculated as above would be an underestimate. This possibility cannot be entirely ruled out. However, as discussed below, the turnover of the pore-water $\mathrm{NO}_{3}{ }^{-}$was most probably controlled principally by diffusion driven by the microalgal demand in the surface layer. Therefore, the heterogeneity of $\mathrm{NO}_{3}{ }^{-}$caused by tight coupling of nitrification with denitrification and its potential effect on in situ denitrification activity were presumably unimportant as factors affecting the overall $\mathrm{NO}_{3}{ }^{-}$dynamics in this sediment.

\section{Microalgal uptake}

Nutrient uptake by microalgae in surface sediments was measured only in the bare-sand area. Nitrate and ammonium were actively taken up by sediment microflora, and the uptake rates were positively correlated with the ambient concentrations $(\mathrm{p}<0.05)$ (Fig. 4).
In winter (March 1998; algal biomass = 3.2 to $3.7 \mu \mathrm{g}$ chl a g $^{-1}$ dry sediment), the average affinity (defined as chl a-based uptake rate divided by substrate concentration) for $\mathrm{NO}_{3}{ }^{-}$in the light $\left(0.45 \pm 0.05 \mathrm{l} \mathrm{mg}^{-1} \mathrm{chl} \mathrm{a}\right.$ $\left.\mathrm{h}^{-1}\right)$ was almost twice that in the dark $(0.22 \pm 0.04 \mathrm{l}$ $\mathrm{mg}^{-1} \mathrm{chl} \mathrm{a} \mathrm{h}^{-1}$ ), suggesting that the observed uptake was directly related to photosynthetic activity of sediment microalgae. The affinity was about 2 orders of magnitude higher than the slopes of the regression lines for denitrification rate- $\mathrm{NO}_{3}{ }^{-}$concentration (Table 2). Thus, the observed uptake could not be ascribable to denitrification. For $\mathrm{NH}_{4}{ }^{+}$, the affinity was considerably higher than for $\mathrm{NO}_{3}{ }^{-}$. The difference between in the light $\left(2.61 \pm 0.25 \mathrm{l} \mathrm{mg}^{-1} \mathrm{chl} \mathrm{a} \mathrm{h}^{-1}\right)$ and dark $\left(2.36 \pm 0.23 \mathrm{l} \mathrm{mg}^{-1} \mathrm{chl} \mathrm{a} \mathrm{h}^{-1}\right)$ incubations was small. The affinity for $\mathrm{NO}_{2}^{-}(0.70 \pm 0.42$ and $0.59 \pm$ $0.44 \mathrm{l} \mathrm{mg}^{-1} \mathrm{chl} \mathrm{a} \mathrm{h}^{-1}$ in the light and dark, respectively) was midway between those for $\mathrm{NO}_{3}{ }^{-}$and $\mathrm{NH}_{4}{ }^{+}$, although the correlation between rate and concentration was very weak (Fig. 4).

In the late-summer experiments (September 1997; algal biomass $=4.7 \mu \mathrm{g} \mathrm{chl} \mathrm{a} \mathrm{g}^{-1}$ dry sediment), only the diurnal-average uptake rates were measured. The chl a-based uptake rates in summer were considerably lower than those in winter (Fig. 4). The diurnalaverage affinities for $\mathrm{NO}_{3}{ }^{-}, \mathrm{NO}_{2}{ }^{-}$and $\mathrm{NH}_{4}{ }^{+}$were $0.17 \pm$ $0.01,0.09 \pm 0.01$ and $0.35 \pm 0.13 \mathrm{l} \mathrm{mg}^{-1} \mathrm{chl} \mathrm{a} \mathrm{h}^{-1}$, respectively. The uptake of $\mathrm{NO}_{3}{ }^{-}$and $\mathrm{NH}_{4}{ }^{+}$was stopped by the addition of a metabolic inhibitor $\mathrm{NaN}_{3}$.

We estimated in situ uptake rates of DIN using the above affinity values and ambient DIN concentrations and assuming that only the microalgae inhabiting the euphotic layer of sediment actively absorbed DIN. The ambient nutrient concentration was assumed to be represented by the pore-water nutrient concentrations
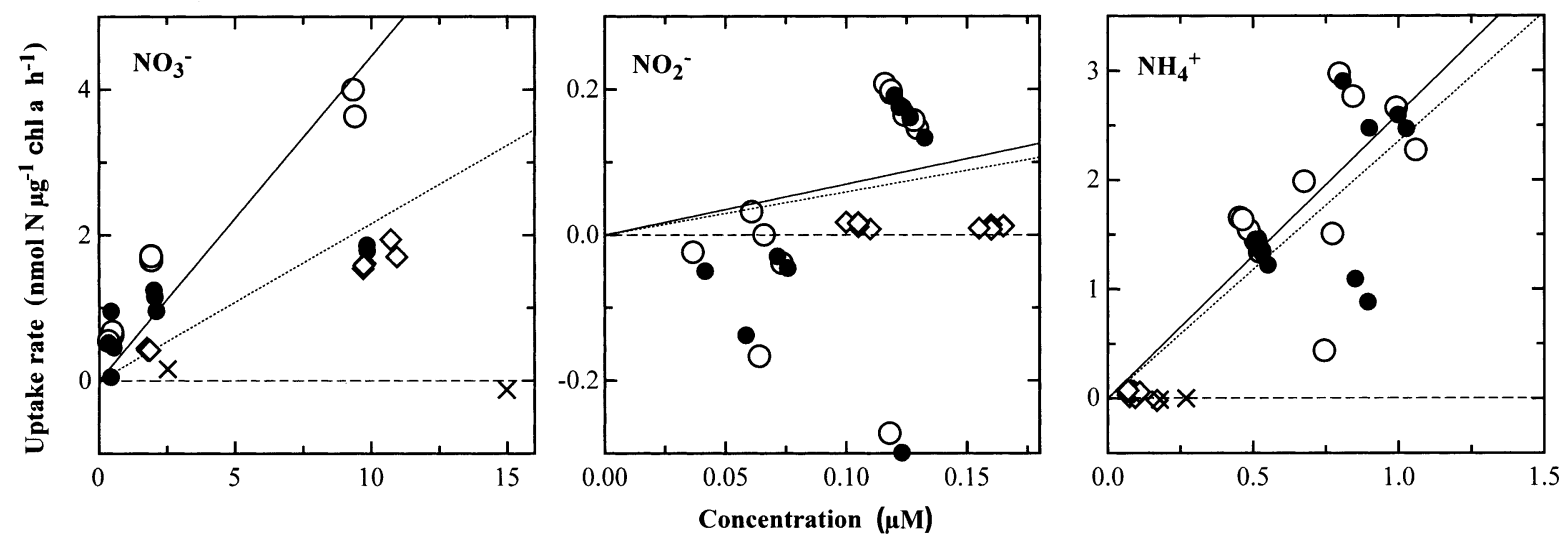

Fig. 4. Relationships between chlorophyll a-based uptake rate of microalgae and ambient concentration of $\mathrm{NO}_{3}^{-}, \mathrm{NO}_{2}^{-}$and $\mathrm{NH}_{4}{ }^{+}$ at the sediment surface measured by bottle-incubation experiments in the bare-sand area in September $1997(\diamond$, live; X, killed by addition of $\left.1 \mathrm{mM} \mathrm{NaN}_{3}\right), 24 \mathrm{~h}$ incubation in ambient light) and March 1998 (O, ambient light; $\bullet$, dark control), $5 \mathrm{~h} \mathrm{incubation}$ in natural daylight). Solid and dotted lines indicate mean affinities (uptake rate divided by substrate concentration) in the light and 
Table 3. Pore-water concentrations, microalgal uptake rates and turnover time of dissolved inorganic nitrogen in the top 4 mm layer (putative euphotic layer) of sediments in the bare-sand area

\begin{tabular}{|c|c|c|c|c|c|c|}
\hline \multirow{2}{*}{$\begin{array}{l}\text { N species, } \\
\text { Season }\end{array}$} & \multicolumn{2}{|c|}{ Concentration $(\mu \mathrm{M})$} & \multicolumn{2}{|c|}{ Uptake rate $\left(\mu \mathrm{mol} \mathrm{m} \mathrm{m}^{-2} \mathrm{~h}^{-1}\right)^{\mathrm{a}}$} & \multicolumn{2}{|c|}{ Turnover time (h) } \\
\hline & Core-1 & Core-2 & Core-1 & Core-2 & Core-1 & Core-2 \\
\hline \multicolumn{7}{|l|}{ Nitrate } \\
\hline September 1997 & 0.76 & 0.99 & 2.86 & 3.61 & 0.78 & 0.83 \\
\hline March 1998 & 1.05 & 1.73 & 5.15 & 8.16 & 0.43 & 0.46 \\
\hline \multicolumn{7}{|l|}{ Nitrite } \\
\hline September 1997 & 0.38 & 0.14 & 0.75 & 0.27 & 1.48 & 1.57 \\
\hline March 1998 & 0.12 & 0.09 & 1.26 & 0.91 & 0.20 & 0.22 \\
\hline \multicolumn{7}{|l|}{ Ammonium } \\
\hline September 1997 & 9.11 & 1.40 & 71.1 & 10.6 & 0.38 & 0.40 \\
\hline March 1998 & 1.16 & 1.89 & 47.4 & 74.3 & 0.05 & 0.06 \\
\hline
\end{tabular}

of the top sediment layer (Fig. 1). Concerning to light penetration in carbonate sediments, a range of 1 to $4 \mathrm{~mm}$ (depending on substrate grain size) for the depth of the euphotic layer has recently been reported from studies using a microphotosensor (Taylor \& Allison 2000, see also Haardt \& Nielsen 1980, Kühl et al. 1994). We assumed therefore that the top $4 \mathrm{~mm}$ layer of the sediment was the euphotic layer and calculated turnover times of DIN in this layer using separately determined water, sand and chl a contents of sediments. The results (Table 3) suggested that the major nitrogen source for the microalgae was $\mathrm{NH}_{4}{ }^{+}$. Assuming that algal organic carbon/chl $a=50(\mu \mathrm{g} / \mu \mathrm{g})$ and organic carbon $/ \mathrm{N}=6.63(\mathrm{~mol} / \mathrm{mol})$, the turnover time of algal-biomass nitrogen at these DIN concentrations is estimated to be 8 to 40 d, i.e. more than 2 orders of magnitude longer than that of DIN in the euphotic layer (Table 3).

It should be noted that primary production rate was poorly correlated with uptake rate of DIN (M.S. unpubl. data). Thus, the validity of the estimates of nutrient uptake rates obtained by measuring primary productivity and assuming that the $\mathrm{C}: \mathrm{N}$ ratio of uptake rates is identical to the $\mathrm{C}: \mathrm{N}$ ratio of algal biomass (e.g. Redfield ratio) is doubtful, although this method has been widely used.

\section{Sediment-water exchange}

Incubation of the intact core samples revealed significant $\mathrm{NO}_{3}{ }^{-}$uptake by the sediments from the overlying water (e.g. Fig. 5). The uptake rate was higher in the seagrass-bed sediment than in the bare-sand sediment (Table 4). In the case of the bare-sand sediment, the $\mathrm{NO}_{3}{ }^{-}$concentration in the overlying water (ca $0.2 \mu \mathrm{M}$ ) was lower than in the pore water (Fig. 1), and the addition of $\mathrm{NaN}_{3}$ did not affect significantly the uptake rate. Nitrate concentrations in the overlying water in the seagrass-beds $(12.5 \mu \mathrm{M}$ in winter and $5.6 \mu \mathrm{M}$ in summer) were higher than those in the pore waters (Fig. 1), suggesting that the higher uptake rate
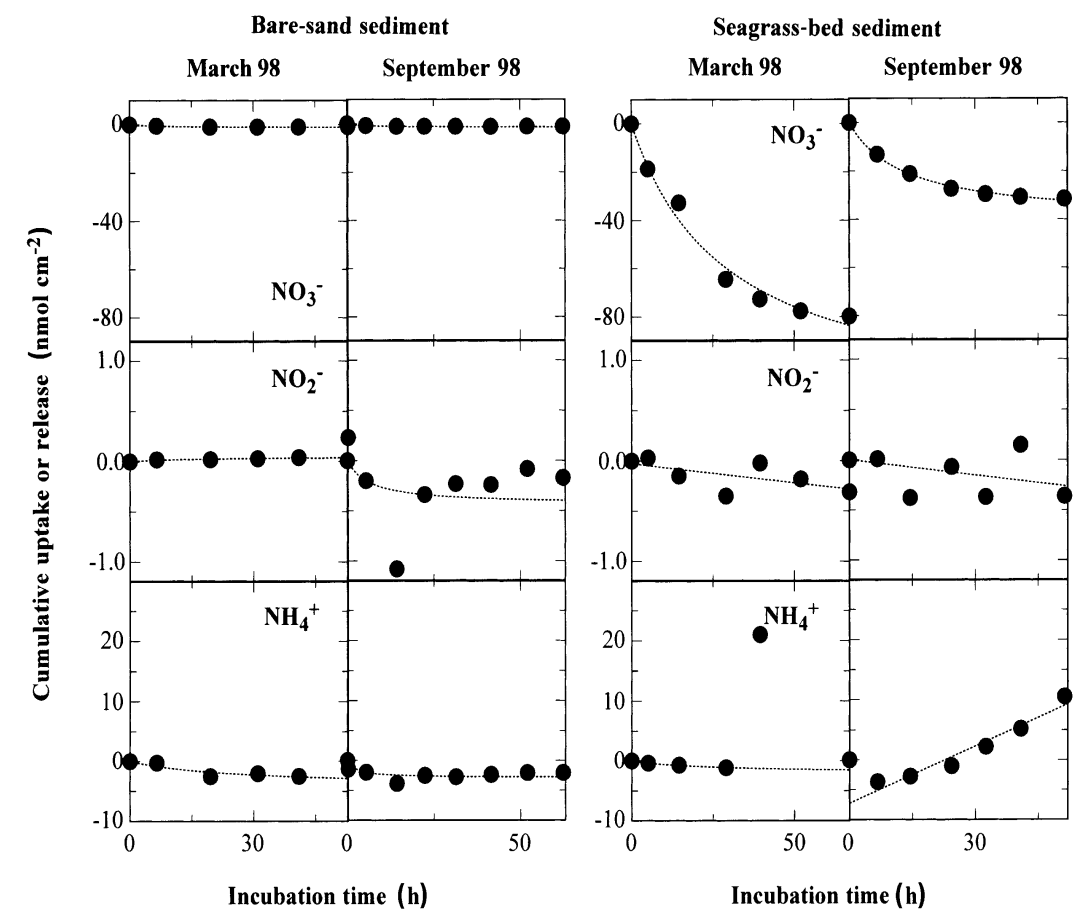

Fig. 5. Net release or uptake of DIN by the sediments from/into the overlying water during dark incubation of intact cores. Cumulative release and uptake (vertical axes) are plotted as a function of incubation time. Positive and negative values indicate net release and uptake by the sediments, respectively 
Table 4. Sediment-water nutrient fluxes observed in dark-incubated intact sand cores. Data are means and SD of 4 cores. Flux data of first 24 to $48 \mathrm{~h}$ of incubation were fitted to linear or hyperbolic curves, and the initial fluxes were calculated by substituting $t=0$ into the curves obtained. Positive and negative values indicate release and uptake by the sediment, respectively

\begin{tabular}{|c|c|c|c|c|}
\hline \multirow{2}{*}{ Season, } & \multicolumn{2}{|c|}{ Bare-sand sediment } & \multicolumn{2}{|c|}{ Seagrass-bed sediment } \\
\hline & Mean & $\mathrm{SD}$ & Mean & $\mathrm{SD}$ \\
\hline \multicolumn{5}{|l|}{ March 1998} \\
\hline Nitrate & -0.212 & 0.072 & -6.43 & 1.71 \\
\hline Nitrite & 0.002 & 0.013 & -0.017 & 0.004 \\
\hline Ammonium & -0.121 & 0.074 & 0.232 & 0.292 \\
\hline \multicolumn{5}{|l|}{ September 1998} \\
\hline Nitrate & -0.341 & 0.089 & -7.89 & 4.36 \\
\hline Nitrite & -0.147 & 0.125 & 0.006 & 0.025 \\
\hline Ammonium & 0.067 & 0.062 & 0.467 & 0.249 \\
\hline
\end{tabular}

turnover time of the algal biomass nitrogen was estimated at 8 to $40 \mathrm{~d}$. Ammonia derived by decomposition of particulate organic nitrogen (PON) in the sediment was presumably the major nitrogen source for the microalgae. The rate of nitrogen fixation was also high, accounting for 6 to $15 \%$ of the microalgal nitrogen demand in the bare-sand sediment. The net external flux of total nitrogen (nitrogen fixation plus net DIN uptake from the overlying water, minus denitrification) accounted for 8 to $13 \%$ of the microalgal demand, showing that the internal supply of DIN within the sediment was the major nitrogen source.

in the seagrass beds was partially ascribable to a steeper concentration gradient of $\mathrm{NO}_{3}{ }^{-}$across the sediment-water interface. $\mathrm{NO}_{3}{ }^{-}$uptake by the seagrassbed sediment decreased to almost half after the addition of $\mathrm{NaN}_{3}$ (data not shown). The concentration of $\mathrm{NO}_{3}{ }^{-}$in the overlying water of the seagrass beds is usually diluted to $<3 \mu \mathrm{M}$ at flood tide (Tanaka 1999) compared to ebb tide (when the cores were sampled). Thus, $\mathrm{NO}_{3}^{-}$uptake by the seagrass-bed sediment during flood tide might be lower than that shown in Table 4. The sediment-water flux of $\mathrm{NO}_{2}^{-}$was generally small, and showed no consistent trend (Fig. 5, Table 4). Ammonium was usually released from the sediment to the overlying water, except for the baresand area in winter (Table 4). The release rate was higher in summer than in winter and higher in the seagrass beds than in the bare-sand area. Release of $\mathrm{NH}_{4}{ }^{+}$seemed to be primarily ascribable to diffusion of $\mathrm{NH}_{4}{ }^{+}$from the pore water, since $\mathrm{NH}_{4}{ }^{+}$concentrations were always higher in the pore water than in the overlying water.

The microalgal uptake potentials in Table 3 are consistently higher than the net DIN uptake in Table 4, suggesting that the main DIN source for the sediment microalgae was the pore-water pool rather than the overlying water.

\section{DISCUSSION}

\section{Nitrogen turnover and budgets in Shiraho Reef sediments}

Among the measured nitrogen fluxes, quantitatively the most important flux was the microalgal uptake of DIN (Table 5). In the bare-sand sediment, $\mathrm{NO}_{3}{ }^{-}$and $\mathrm{NH}_{4}{ }^{+}$in the top layer could be turned over within $1 \mathrm{~h}$ by active microalgal uptake (Table 3), while the
Since the sand cover over the bedrocks of this lagoon is shallow, we assumed that the top $15 \mathrm{~cm}$ layer of the sediment was responsible for the internal DIN recycling. The average turnover time of pore-water DIN in this layer due to microalgal uptake was estimated to be 0.5 to $2 \mathrm{~d}$. This estimate is comparable to the turnover time of pore-water $\mathrm{NO}_{3}{ }^{-}$due to denitrification (Table 2). For these DIN demands to be compensated by mineralization of PON, the sediment PON in this layer should be turned over within 3 to $8 \mathrm{yr}$. This would be a minimum estimate for PON turnover rate, since we have not taken into account the possibly large DIN demand by heterotrophic microorganisms in the aphotic layer of the sediment.

Microalgal DIN turnover was also estimated for the seagrass-bed sediment, assuming that the uptake affinities for DIN are the same as in the bare-sand sediment (Table 5). Algal biomass (chl a) was $1.28 \pm 0.65$ times higher in the seagrass-bed than in the bare-sand sediments (average of 5 transects; H. Kayanne et al. unpubl. data). The calculated turnover times of PON and pore-water DIN in the seagrass-bed sediment were on the same order as the respective turnover times in the bare-sand sediment. External fluxes contributed 18 to $35 \%$ of the microalgal nitrogen demand. The external flux was much higher in the seagrass-bed area (average $7.3 \mathrm{nmol} \mathrm{N} \mathrm{cm}^{-2} \mathrm{~h}^{-1}$ ) than in the baresand area (average $0.56 \mathrm{nmol} \mathrm{N} \mathrm{cm}^{-2} \mathrm{~h}^{-1}$ ). Although $\mathrm{NH}_{4}{ }^{+}$as the major source for algal nitrogen uptake was suggested by calculation based on pore-water chemistry, $\mathrm{NO}_{3}{ }^{-}$derived from groundwater may be another significant source of algal nitrogen in the seagrass beds.

Thus, we can distinguish 3 distinct characteristic times in the turnover of nitrogen pools: $(1)<1 \mathrm{~h}$ for pore-water DIN in the euphotic layer of the sediment; (2) an order of days for microalgal biomass and porewater DIN in the aphotic layer; and (3) a few years for 
PON. The net external flux of nitrogen was positive in both the bare-sand area and the seagrass beds, indicating that these sediment systems were accumulating nitrogen from the environment. Although the fate of this accumulated nitrogen is not known, a possible hypothesis is that nitrogen is accumulated in the microalgae via the pore-water pool and then exported from the sediment by resuspension or grazing. Nitrogen accumulated in the seagrass-bed sediment may also be assimilated by the seagrasses through the roots and eventually exported from the system as dead seagrass leaves and seagrass-derived detritus (Moriarty \& Boon 1989).

It seems a conspicuous characteristic of shallow lagoonal sediments of coral reefs that epibenthic microalgae effectively trap dissolved nutrients diffusing up from the sediments. In so doing, they enhance nutrient storage in the sediments and increase the relative importance of the internal nutrient recycling as opposed to nutrient exchange with the overlying water. It has long been assumed that the relative importance of internal nutrient recycling is the key to understanding the high productivity of coral reefs and seagrass beds in oligotrophic tropical and subtropical waters (D'Elia \& Wiebe 1990). However, direct evidence for this hypothesis is scarce. The results we present here support this hypothesis for a subsystem (lagoonal sediments) of the coral reef ecosystem.

\section{Regulating factors of nitrogen cycling}

Rates of external nitrogen fluxes were generally higher in the seagrass-bed sediment than in the baresand area. Although few studies have simultaneously measured these nitrogen fluxes in both bare carbonate-sand sediment and adjacent seagrass beds, a comparison of independently measured data found in the literature supports this general trend (Table 5). The larger nitrogen fluxes in seagrass beds can be explained by several factors. Firstly, seagrass beds are generally located near the land and affected by landderived nitrogen, including groundwater $\mathrm{NO}_{3}^{-}$; this will increase the nitrogen uptake and stock in the seagrass-bed sediments. Secondly, seagrass bed sediments generally contain greater amounts of organic carbon than unvegetated sediments because of the higher organic production by seagrasses (e.g. Boon 1986). The better availability of organic carbon will enhance heterotrophic nitrogen fixation and denitrification. Thirdly, seagrass beds reduce the mobility of sediment particles compared to unvegetated areas (Fonseca 1989). This leads to an exchange of nitrogen between the sediment and the ambient water preferentially in dissolved rather than particulate form.
The extent to which the availability of light limits nitrogen-fixing activity in the sediments varies between different coral reefs. In the case of Shiraho reef, light availability strongly limited nitrogen fixation (Fig. 2), suggesting that the principal agents for nitrogen fixation in the sediments were cyanobacteria or some heterotrophic bacteria that depended on organic carbon produced by proximal benthic microalgae. Such a clear light dependence has not always been evidenced in other coral reefs. In a study of several reefs in the subtropical Atlantic and the Great Barrier Reef, O'Neil \& Capone (1989) concluded that light was not the principal limiting factor for nitrogen fixation in carbonate sediments. Hanson \& Gunderson (1976) also reported that only $50 \%$ of the nitrogen fixation activity in Kaneohe Bay sediments depended on light. Light dependence of sediment nitrogen fixation may be an indicator of a shortage of energy (organic) storage that could support nitrogen fixation in the dark, relative to other potential limiting factors such as availability of phospherus and molybdenum.

The fact that the denitrification rate in the sediments was stimulated by the addition of extra $\mathrm{NO}_{3}{ }^{-}$(Fig. 3) suggests that the availability of $\mathrm{NO}_{3}{ }^{-}$was a limiting factor for denitrification. A similar observation was previously reported for other carbonate sediments by Corredor \& Capone (1985). In our study, $\mathrm{NO}_{3}{ }^{-}$stimulation was also observed in the seagrass-bed sediment, where depletion of $\mathrm{NO}_{3}{ }^{-}$in the pore water of the deeper layers indicated that $\mathrm{NO}_{3}{ }^{-}$availability more strongly limited the denitrification rate than availablity of organic substrates. In Shiraho Reef, seepage of groundwater sometimes supplies high concentrations (up to $50 \mu \mathrm{M}$ ) of $\mathrm{NO}_{3}{ }^{-}$to the seagrass beds. Denitrification may play a role as a major sink of groundwaterderived $\mathrm{NO}_{3}{ }^{-}$in the seagrass beds, preventing the whole reef ecosystem from eutrophication. In contrast, a measurable concentration of $\mathrm{NO}_{3}^{-}(>1 \mu \mathrm{M})$ was always found in the pore waters of the bare-sand area (except for the surface layer in direct contact with the $\mathrm{NO}_{3}{ }^{-}$-depleted overlying water), indicating that availability of organic matter was the stronger limiting factor of denitrification in this type of sediment.

\section{Comparison with other coral reefs}

The rates of nitrogen fixation and denitrification measured in the bare-sand sediment of Shiraho Reef are within the ranges reported for other tropical carbonate sediments (Table 5). Available data for $\mathrm{NO}_{3}{ }^{-}$and $\mathrm{NH}_{4}{ }^{+}$ fluxes across the sediment/water interface of other reef sites are very few, but consistently indicate a more negative flux (i.e. release from the sediment) than is the case for Shiraho Reef. This difference, however, 
may arise from differences in methods of estimation, since the other researchers (Corredor \& Morell 1985, Capone et al. 1992) calculated DIN fluxes using porewater DIN profiles and general diffusion coefficients. When applied to euphotic sediments, this latter method tends to yield values biased for efflux from the sediments because it does not take into account the fact that the DIN flux from the deeper sediment would be at least partially consumed at the surface by epibenthic algae. Therefore, there is no clear indication that the external nitrogen fluxes in the bare-sand area of Shiraho Reef is significantly different from that in other coral reefs.

In contrast, the rates of nitrogen fixation and denitrification observed in the seagrass beds of Shiraho Reef are significantly lower than corresponding rates in seagrass beds of other regions of the world (Table 5). Although available data for $\mathrm{NO}_{3}{ }^{-}$and $\mathrm{NH}_{4}{ }^{+}$fluxes are very few, Shiraho seagrass-bed sediment seems to be characterized by a high $\mathrm{NO}_{3}{ }^{-}$uptake and a relatively low flux of $\mathrm{NH}_{4}{ }^{+}$. The high $\mathrm{NO}_{3}^{-}$uptake in Shiraho seagrass-bed sediment is presumably due to the relatively high $\mathrm{NO}_{3}{ }^{-}$concentration in the overlying water, which, in turn, is ascribable to groundwater inflow. The low nitrogen fixation rate may also be related to relatively nitrogen-rich conditions supported by the influx of groundwater $\mathrm{NO}_{3}{ }^{-}$. However, since $\mathrm{NO}_{3}{ }^{-}$availability in groundwater-affected coastal areas such as Shiraho seagrass beds is extremely variable, both spatially and temporally, we cannot draw quantitative conclusions about the effects of groundwater inflow on sediment nitrogen metabolism from the limited amount of data available.

Microalgal DIN uptake is by far the largest potential nitrogen flux in the surface sediments (Table 5), indicating greater importance of internal nitrogen recycling as opposed to external fluxes. Although there are few studies which directly compare the internal and external fluxes in coral-reef sediments, Boucher et al. (1994) reported potential microalgal DIN uptake rates that were in the same order as those reported here. Capone et al. (1992) determined production and net assimilation of $\mathrm{NH}_{4}{ }^{+}$as a measure of internal flux and compared them with the external fluxes in several reefs of the Great Barrier Reef. Although Capone et al. did not directly assess microalgal uptake, their data clearly evidenced the importance of the internal flux. Ammonium production is the major nitrogen flux in seagrass beds also (Moriarty \& Boon 1989). Although the contribution of epibenthic microalgae to organic production in seagrass beds has been shown to be potentially predominant (Moncreiff et al. 1992, Pollard \& Kogure 1993), their relative importance in DIN turnover in seagrass-bed sediments is little understood.
The role of the microalgal community in the nitrogen turnover of bare carbonate sediments and seagrassbeds is one of the overlooked themes in the biogeochemical study of coral reefs. More extensive studies are needed to elucidate the possible roles of benthic microalgae in regulating nutrient stocks and fluxes in the sediment and exporting food sources to downstream filter-feeding animals.

Acknowledgements. This work was supported by CREST (Core Research for Evolutional Science and Technology) of the Japan Science and Technology Corporation (JST). Field samplings were assisted by H. Kayanne (The University of Tokyo), H. Hata (JST) and H. Yamano (National Institute for Environmental Studies, Japan).

\section{LITERATURE CITED}

Blackburn TH, Nedwell DB, Wiebe WJ (1994) Active mineral cycling in a Jamaican seagrass sediment. Mar Ecol Prog Ser 110:233-239

Boon PI (1986) Uptake and release of nitrogen compounds in coral reef and seagrass, Thalassia hemprichii (Ehrenb) Aschers, bed sediments at Lizard Island, Queensland. Aust J Mar Freshw Res 37:95-117

Boucher G, Clavier J, Garrigue C (1994) Estimation of bottom ammonium affinity in the New Caledonia lagoon. Coral Reefs 13:13-19

Capone DG, Taylor BF (1980) $\mathrm{N}_{2}$ fixation in the rhizosphere of Thalassia testudinum. Can J Microbiol 26:998-1005

Capone DG, Taylor DL, Taylor BF (1977) Nitrogen fixation (acetylene reduction) associated with macroalgae in a coral-reef community in Bahamas. Mar Biol 40:29-32

Capone DG, Dunham SE, Horrigan SG, Duguay LE (1992) Microbial nitrogen transformations in unconsolidated coral reef sediments. Mar Ecol Prog Ser 80:75-88

Charpy-Roubaud C, Charpy L, Sarazin G (1996) Diffusional nutrient fluxes at the sediment-water interface and organic matter mineralization in an atoll lagoon (Tikehau, Tuamotu Archipelago, French Polynesia). Mar Ecol Prog Ser 132:181-190

Corredor JE, Capone DG (1985) Studies on nitrogen diagenesis in coral reef sands. Proc 5th Int Coral Reef Congr 3: 395-399

Corredor JE, Morell J (1985) Inorganic nitrogen in coral reef sediments. Mar Chem 16:379-384

D'Elia CF, Wiebe WJ (1990) Biogeochemical nutrient cycles in coral-reef ecosystems. In: Dubinski Z (ed) Ecosystems of the world, Vol 25. Coral reefs. Elsevier Science Publishers BV, Amsterdam, p 49-74

Erftemeijer PLA, Middelburg JJ (1993) Sediment-nutrient interactions in tropical seagrass-beds: a comparison between a terrigenous and a carbonate sedimentary environment in South Sulawesi (Indonesia). Mar Ecol Prog Ser 102:187-198

Fonseca MS (1989) Sediment stabilization by Halophila decipiens in comparison to other seagrasses. Estuar Coast Shelf Sci 29:501-507

Haardt H, Nielsen G (1980) Attenuation measurements of monochromatic light in marine sediments. Oceanol Acta 3: 333-338

Hanson RB, Gunderson KB (1976) Bacterial nitrogen fixation in a polluted coral reef flat ecosystem, Kaneohe Bay, Oahu, Hawaiian Islands. Pac Sci 30:385-393 
Hemminga MA, Harrison PG, van Lent F (1991) The balance of nutrient losses and gains in seagrass meadows. Mar Ecol Prog Ser 71:85-96

Hopkinson J, Charles S, Sherr BF, Ducklow HW (1987) Microbial regeneration of ammonium in the water column of Davies Reef, Australia. Mar Ecol Prog Ser 41:147-153

Iizumi H, Hattori A, McRoy CP (1980) Nitrate and nitrite in interstitial waters of eelgrass beds in relation to rhizosphere. J Exp Mar Biol Ecol 47:191-201

Joye SB, Smith SV, Hollibaugh JT, Paerl HW (1996) Estimating denitrification rates in estuarine sediments: a comparison of stoichiometric and acetylene based methods. Biogeochemistry 33:197-215

Kasper HF (1983) Denitrification, nitrate reduction to ammonium, and inorganic nitrogen pools in intertidal sediments. Mar Biol 74:133-139

Kester DR (1975) Dissolved gases other than $\mathrm{CO}_{2}$. In: Riley JP, Skirrow G (eds) Chemical oceanography, Vol 1, 2nd edn. Academic Press, London, p 497-556

Kühl M, Lassen C, Jørgensen BB (1994) Light penetration and light intensity in sandy marine sediments measured with irradiance and scalar irradiance fiber-optic microprobes. Mar Ecol Prog Ser 105:139-148

Larkum AWD, Kennedy IR, Muller WJ (1988) Nitrogen fixation on a coral reef. Mar Biol 98:143-155

Lewis JB (1977) Processes of organic production on coral reefs. Biol Rev 52:305-347

Miyajima T, Koike I, Yamano H, Iizumi H (1998) Accumulation and transport of seagrass-derived organic matter in reef flat sediment of Green Island, Great Barrier Reef. Mar Ecol Prog Ser 175:251-259

Moncreiff C, Sullivan MJ, Daehnick AE (1992) Primary production dynamics in seagrass-beds of Mississippi Sound: the contributions of seagrass, epiphytic algae, sand microflora, and phytoplankton. Mar Ecol Prog Ser 87:161-171

Moriarty DJW, Boon PI (1989) Interactions of seagrasses with sediment and water. In: Larkum AWD, McComb AJ, Shepherd SA (eds) Biology of seagrasses: a treatise on the biology of seagrasses with special reference to the Australian region. Elsevier, Amsterdam, p 500-535

Moriarty DJW, O'Donohue MJ (1993) Nitrogen fixation in seagrass communities during summer in the Gulf of Carpentaria, Australia. Aust J Mar Freshw Res 44:117-125

Nakamori T, Suzuki A, Iryu Y (1992) Water circulation and carbon flux on Shiraho coral reef of the Ryukyu Islands, Japan. Cont Shelf Res 12:951-970

Editorial responsibility: Otto Kinne (Editor), Oldendorf/Luhe, Germany
O'Neil JM, Capone DG (1989) Nitrogenase activity in tropical marine carbonate sediment. Mar Ecol Prog Ser 56: $145-156$

Pollard PC, Kogure K (1993) The role of epiphytic and epibenthic algal productivity in a tropical seagrass, Syringodium isoetifolium (Aschers) Dandy, community. Aust J Mar Freshw Res 44:141-154

Porra RJ, Thompson WA, Kriedemann PE (1989) Determination of accurate extinction coefficients and simultaneous equations for assaying chlorophylls $a$ and $b$ extracted with four different solvents: verification of the concentration of chlorophyll a standards by atomic absorption spectroscopy. Biochim Biophys Acta 975:384-394

Seitzinger SP, Garber JH (1987) Nitrogen fixation and ${ }^{15} \mathrm{~N}_{2}$ calibration of the acetylene reduction assay in coastal marine sediments. Mar Ecol Prog Ser 37:65-73

Short FT (1983) The response of interstitial ammonium in eelgrass (Zostera marina L.) beds to environmental perturbations. J Exp Mar Biol Ecol 68:195-208

Strickland JDH, Parsons TR (1968) A practical handbook of seawater analysis. Bull Fish Res Board Can 167

Taylor BB, Allison MA (2000) Characterization of the insediment light field of sandy coastal environments. EOS $80(49): 111$

Tanaka Y (1999) Distribution of seagrasses in Ishigaki Island and its regulating factors. MSc thesis, Faculty of Science, The University of Tokyo (in Japanese with English abstract)

Umezawa Y (2000) Studies on terrestrial nitrogen load to subtropical coral reef area evaluated by chemical composition of macroalgae. MSc thesis, Faculty of Science, The University of Tokyo (in Japanese with English abstract)

Webb KL, DuPaul WD, Wiebe W, Sottile W, Johannes RE (1975) Enewetak (Eniwetok) Atoll: aspects of the nitrogen cycle on a coral reef. Limnol Oceanogr 20:198-210

Wiebe WJ (1985) Nitrogen dynamics on coral reefs. Proc 5th Int Coral Reef Congr 3:401-406

Wiebe WJ, Johannes RE, Webb KL (1975) Nitrogen fixation in a coral reef community. Science 188:257-259

Williams SL, Gill IP, Yarish SM (1985) Nitrogen cycling in backreef sediments (St. Croix, US Virgin Islands). Proc 5th Int Coral Reef Congr 3:389-394

Ziegler S, Benner R (1999) Nutrient cycling in the water column of a subtropical seagrass meadow. Mar Ecol Prog Ser 188:51-62

Submitted: March 31, 2000; Accepted: December 8, 2000 Proofs received from author(s): June 26, 2001 